\title{
Babel digital
}

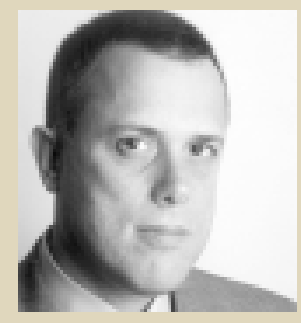

Nelson Lerner Barth FGV-EAESP

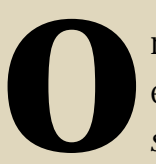

rganizações estão continuamente envolvidas no desenvolvimento de software para fazer frente às suas mais diversas necessidades: da gestão de materiais ao atendimento ao cliente. Diantedetais projetos, seus profissionais podem sever em um mar desiglas. $\mathrm{E}$ o mundo digital é repleto delas, algumas impenetráveis. Sua proliferação ocorre tanto por razões técnicas como por razões comerciais. Alguns vêem o fenômeno como exemplo do comportamento de gueto dos profissionais de informática, pouco interessados nas reais necessidades esempreprontos a lançar uma cortina de fumaça sobre suas atividades. Teorias conspiratórias à parte, vamos tomar três siglas que aparecem com freqüência quando 0 tema é projeto de software: SW-CMM, UML eXP.

SW-CMM significa "Software Capability Maturity Model", um modelo que descreve as chaves para processos eficientes de desenvolvimento de software.

UML significa "Unified Modeling Language". Trata-se de uma tentativa de padronização das notações para as diversas fases do projeto de software: modelos semânticos, notação sintática e diagramas, permitindo um projeto visual do software bem antes de implementá-lo.

XP significa "Extreme Programming" - método que privilegia a comunicação informal entre os projetistas, a simplicidade de projeto, a revisão do código e testes constantes. Seu uso é destinado a equipes que estejam desenvolvendo software com requisitos imprecisos ou mutáveis.
Essas siglas podem ser utilizadas de forma complementar. Tomemos o caso do XP, que às vezes é considerado antagônico aos conceitos do SW-CMM e da UML. Eleé criticado como sendo uma forma indisciplinada de desenvolvimento de software, visto que nega a seqüência tradicional de projeto. Os defensores do XP afirmam que 0 processo de desenvolvimento de software se assemelha mais à redação de um livro - repleta de idas e vindas - do queà construção de uma casa que começa por projeto arquitetônico e firmes alicerces. 0 XP contraria claramente 0 conceito de "maturidade" dos processos preconizado pelo CMM. Porém, para pequenas e médias equipes, várias características do XP podem se adaptar aos requisitos dos processos do CMM.

Diz-se que UML inviabiliza a adoção do XP. Entretanto, XP pode sim utilizar conceitos da UML, mas em uma fase posterior, a da documentação do projeto realizado.

Desta forma, CMM, UML e XP não devem ser considerados como al ternativas excludentes; devem ser vistos pelas empresas e pelas equipes de desenvolvimento de software de acordo com 0 contexto de cada projeto.

Embora os defensores de um ou outro modelo eventualmente assumam "zelo religioso" em sua defesa, uma postura mais recomendável a esses profissionais, e principalmente a seus clientes, é uma postura pragmática, que permita a correta combinação de abordagens em benefício do produto final. 